\title{
Mechanism underlying the immune checkpoint inhibitor-induced hyper-progressive state of cancer
}

\author{
Peng Ding\#, Lu Wen\#, Fan Tong, Ruiguang Zhang, Yu Huang, Xiaorong Dong \\ Cancer Center, Union Hospital, Tongji Medical College, Huazhong University of Science and Technology, Wuhan 430022, \\ Hubei, China. \\ \#Authors contributed equally.
}

Correspondence to: Dr. Xiaorong Dong, Cancer Center, Union Hospital, Tongji Medical College, Huazhong University of Science and Technology, No.109 Machang Road, Jianghan District, Wuhan 430022, Hubei, China. E-mail: xiaorongdong@hust.edu.cn

How to cite this article: Ding P, Wen L, Tong F, Zhang R, Huang Y, Dong X. Mechanism underlying the immune checkpoint inhibitor-induced hyper-progressive state of cancer. Cancer Drug Resist 2022;5:147-64.

https://dx.doi.org/10.20517/cdr.2021.104

Received: 27 Sep 2021 First Decision: 7 Dec 2021 Revised: 27 Dec 2021 Accepted: 10 Jan 2022 Published: 8 Feb 2022

Academic Editors: Chunxia Su, Godefridus J. Peters Copy Editor: Yue-Yue Zhang Production Editor: Yue-Yue Zhang

\begin{abstract}
Immune checkpoint inhibitors (ICls) are gradually replacing chemotherapy as the cornerstone of the treatment of advanced malignant tumors because of their long-lasting and significant effect in different tumor types and greatly prolonging the survival time of patients. However, not all patients can respond to $\mathrm{ICls}$, and even rapid tumor growth after treatment with $\mathrm{ICI}$ has been observed in a number of clinical studies. This rapid progression phenomenon is called hyper-progressive disease (HPD). The occurrence of HPD is not uncommon. Past statistics show that the incidence of HPD is $4 \%-29 \%$ in different tumor types, and the progression-free survival and overall survival of patients with HPD are significantly shorter than those of the non-HPD progressor group. With the deepening of the study of HPD, we have established a preliminary understanding of HPD, but the diagnostic criteria of HPD are still not unified, and the addition of biomarkers may break this dilemma. In addition, quite a few immune cells have been found to be involved in the occurrence and development of HPD in the tumor microenvironment, indicating that the molecular mechanism of HPD may be triggered by a variety of ongoing events at the same time. In this review, we summarize past findings, including case reports, clinical trials, and fundamental research; compare the diagnostic criteria, incidence, and clinical prognostic indicators of HPD in different studies; and explore the molecular mechanism and future research direction of HPD.
\end{abstract}


Keywords: Immune checkpoint inhibitors, hyper-progressive disease, immunotherapy, tumor microenvironment

\section{INTRODUCTION}

Immune checkpoint inhibitors (ICIs) have continuously promoted the progress of the treatment of malignant tumors since their advent. They have gradually replaced chemotherapy as the cornerstone for the treatment of malignant tumors; however, ICIs are only effective in some patients and remain ineffective in most populations. Changes in the tumor microenvironment (TME) induced by ICIs stimulate the accelerated growth of malignant tumor cells. This special tumor progression mode is called the hyperprogressive disease (HPD) state. Lahmar et al. ${ }^{[1]}$ reported the HPD phenomenon for the first time in a wall newspaper at the 2016 European Society of Medical Oncology Annual Meeting. Eight patients with advanced non-small cell carcinoma (NSCLC) exhibiting fast progression at the time of initial examination were identified as HPD cases. HPD gained attention in 2017 when Champiat $e t$ al. ${ }^{[2]}$ reported a 9\% HPD incidence in 131 cancer patients in a phase I prospective study. Evidence of HPD, the phenomenon of early crossover of the survival curve, is also reported in some phase III clinical studies, including in NSCLC (CheckMate026 $6^{[3]}$, CheckMate057 $7^{[4]}$, and CheckMate227 $7^{[5]}$ ), HNSCC (CheckMate141 ${ }^{[6]}$ ), and uroepithelial carcinoma (Keynote045 $5^{[7]}$ and IMvigor $211^{[8]}$ ). Patients receiving immunotherapy died at a greater rate in the first three months than those treated with chemotherapy. HPD is not unique to immunotherapy and can also be caused by chemotherapy ${ }^{[9]}$ and targeted therapy ${ }^{[10]}$. However, the incidence of HPD after ICI treatment is significantly higher than in the chemotherapeutic regime ${ }^{[11]}$. Since its discovery in 2016 , several studies on HPD have been reported in the last five years. Nevertheless, the incidence, diagnostic criteria, and pathogenesis of HPD remain in the preliminary stages. This review summarizes the recently published cases, clinical studies, and basic studies on HPD.

\section{DIAGNOSTIC CRITERIA FOR HPD}

At present, there is no agreement on the diagnostic criteria of HPD. Although many clinical studies on HPD adopt different diagnostic criteria, the diagnostic indicators of HPD mainly focus on the following five: tumor growth rate (TGR), $\Delta$ TGR, tumor growth kinetics (TGK), Response Evaluation Criteria in Solid Tumors (RECIST), and time to failure (TTF). TGR represents the percentage of monthly tumor volume growth (excluding new and immeasurable lesions), and the difference between the two at and before treatment is defined as $\triangle \mathrm{TGR}$. TGK is defined similarly to TGR, but it primarily reflects tumor growth rate per unit time. TTF refers to the time of treatment failure. Champiat et al. ${ }^{[2]}$ earlier adopted such criteria as TGR $>2$ and RECIST to assess the progress for the first time to define HPD. In the same year, Ferrara et al. ${ }^{[9]}$ used a different cut-off value of $\Delta \mathrm{TGR}>50 \%$. Kato et al ${ }^{[12]}$ added TTF $<2$ months on the basis of predecessors. Saâda-Bouzid et al. ${ }^{[13]}$ used a new index, TGK, as a measure of tumor growth rate that may be more appropriate to define HPD. Kim et al. ${ }^{[14]}$ reviewed the survival time of 335 patients with advanced NSCLC who received ICI monotherapy; it was proved that HPD defined by volume measurement (TTF $<2$ months, TGK $>2$, and $\Delta \mathrm{TGR}>50 \%$ ) is more accurate than that defined based on one-dimensional analysis (RECIST 1.1). Kas et al. ${ }^{[15]}$ conducted a retrospective study of 406 patients with advanced NSCLC treated with ICIs. They calculated their results using the different definitions of five clinical studies. The incidence of HPD ranged from $5.4 \%$ to $18.5 \%$, and the median survival ranged from 3.4 to 6.0 months. $\Delta$ TGR was found to be most correlated with poor prognosis, and $\Delta \mathrm{TGR}>100 \%$ was updated as the optimal threshold.

Although the volumetric method is superior to the RECIST standard, there are practical problems: first, not all patients can complete the pre-baseline computed tomography (CT) scan, especially those receiving ICI as late first-line treatment. Second, new and unmeasurable lesions cannot be measured by TGR. 
Matos et al. ${ }^{[1,1,1]]}$ returned to RECIST standard and proposed a new method to define HPD: (1) target lesions increased by more than $40 \%$ from baseline; and/or (2) target lesions increased by more than $20 \%$ from baseline and new lesions appeared in at least two different organs. The overall survival (OS) of the HPD group using the new standard decreased significantly, which was statistically significant, compared to the non-HPD group, whereas the OS of the HPD group using TGR decreased, but not statistically significantly. However, Gomes da Morais et al. ${ }^{[18]}$ reviewed the literature and compared the main criteria of HPD proposed by Ferté, Le Tourneau, Garralda, and Caramella. These criteria include $\Delta$ TGR $>100$ (Caramella) and $20 \%$ target lesion progression plus the occurrence of new lesions in at least two different organs. The incidence of HPD was $23.9 \%, 23.9 \%, 32.4 \%$ and $8.4 \%$, respectively. They believed that the Caramella standard has low sensitivity; the Garralda standard has low specificity; and the Le Tourneau and Ferté standards seem to have similar performance in detecting HPD, but, from a practical point of view, the twodimensional evaluation of TGK (Le Tourneau) is easier than the three-dimensional evaluation of TGR (Ferté). The importance of pre-baseline CT scanning in diagnosing HPD was thus highlighted, but only 71 eligible patients were enrolled in this study. Later, Abbar et al. ${ }^{[19]}$ expanded the study to 169 advanced NSCLC patients treated with ICI; the incidence of HPD (11.3\%, 5.7\%, 17.0\%, 9.6\% and 31.7\%) was calculated based on five indicators. In addition to the discovery of large heterogeneity, the definition of HPD based on TTF standard was correlated with OS, while the other diagnostic criteria were not correlated with OS.

Thus, combining indicators with each other may be more conducive to diagnosis. The radiological and clinical diagnostic criteria for HPD are still being explored. With the deepening of the understanding of biomarkers for HPD, biomarkers may be involved in the diagnostic criteria of HPD in the future, and the joint definition of HPD by three diagnostic methods may be more accurate and practical.

\section{INCIDENCE AND PROGNOSTIC INDICATORS OF HPD}

The incidence and clinical prognostic indicators of HPD are also different. Chen et al. ${ }^{[20]}$ reviewed the medical records of 377 patients with multiple malignancies and reported the incidence of HPD (10.08\%). Factors associated with HPD include the presence of more than two metastatic sites, Eastern Cooperative Oncology Group score $\geq 2$, liver metastasis, and lactic dehydrogenase level higher than the normal upper limit. Kirsten rat sarcoma viral oncogene homolog status is significantly correlated with HPD in colon cancer patients. Two large-scale meta-analyses reported the incidence of HPD in patients with pan-cancer as $1 \%-30 \%{ }^{[2]]}$ and $5.9 \%-43.1 \%{ }^{[22]}$. The clinical prognostic markers used in these analyses were similar to those reported by Chen et al..$^{[20]}$. Ferrara et al..$^{[0]}$, using RECIST 1.1 and TGR criteria, reported a $13.8 \%(56 / 406)$ HPD incidence in patients with advanced NSCLC; HPD was associated with more than two metastases before immunotherapy. Kim et al. ${ }^{[23]}$ first defined three criteria (TGR, TGK, and TTF) to calculate the incidence of HPD $(20.9 \%, 20.5 \%$, and $37.3 \%$, respectively). In HPD patients who satisfied both TGR and TGK criteria, poorer progression-free survival (PFS) and OS were observed. Although no clinicopathological variables of HPD were reported in the study, in the exploratory biomarker analysis of peripheral blood, $\mathrm{CD}^{+} \mathrm{T}$ lymphocytes, lower effector/memory subsets (CCR7 CD45RA- $\mathrm{T}$ cells in total $\mathrm{CD}^{+} \mathrm{T}$ cells), and higher populations of severely depleted cells ( $\mathrm{TIGIT}^{+} \mathrm{T}$ cells in $\mathrm{PD}-1^{+} \mathrm{CD}^{+} \mathrm{T}$ cells) were associated with HPD and poor survival. In two real-world studies, the incidence of HPD in advanced NSCLC was $19.2 \%(16 / 83)^{[24]}$ and $8.1 \%(6 / 74)^{[25]}$. Among them, one study reported an increased rate of fluid accumulation (up to 90\%) and decreased albumin level, while the other showed a significant increase in the number of circulating Treg cells in HPD patients. Chen et al. ${ }^{[26]}$ performed a meta-analysis consisting of 1389 NSCLC patients from six clinical studies and found that the incidence of HPD was $8.02 \%-30.43 \%$. The incidence of HPD and clinical prognostic indicators in cancer types are shown in Table 1. 
Table 1. Recent retrospective studies on hyper-progression after immunotherapy

\begin{tabular}{|c|c|c|c|c|c|c|}
\hline $\begin{array}{l}\text { Tumor } \\
\text { type }\end{array}$ & Agents & HPD criteria & HPD incidence & Prognostic indicators & $\begin{array}{l}\text { Outcomes (HPD vs. } \\
\text { non-HPD) }\end{array}$ & Ref. \\
\hline $\begin{array}{l}\text { Multiple } \\
\text { tumor } \\
\text { types }\end{array}$ & $\begin{array}{l}\text { PD-1/PD-L1 inhibitor } \\
\text { monotherapy }\end{array}$ & - & $1 \%-30 \%(217 / 1519)$ & $\begin{array}{l}\text { Serum LDH > upper normal limit; > } \\
2 \text { metastatic sites prior to } \\
\text { immunotherapy; liver metastatic } \\
\text { sites; RMH prognostic score } \geq 2 ; \\
\text { positive PD-L1 expression status }\end{array}$ & - & Kim et al. $^{[21]}$ (2019) \\
\hline $\begin{array}{l}\text { Multiple } \\
\text { tumor } \\
\text { types }\end{array}$ & $\begin{array}{l}\text { PD-1/PD-L1 inhibitor } \\
\text { monotherapy }\end{array}$ & $\begin{array}{l}\text { RECIST criteria }(1.4 \times \text { baseline sum target lesions or } \\
1.2 \times \text { baseline sum target lesions }+ \text { new lesions in at } \\
\text { least } 2 \text { different organs) or TGR } \geq 2\end{array}$ & $\begin{array}{l}\text { RECIST criteria, } 10.7 \% \\
(29 / 270) ; \text { TGR criteria, } \\
6.3 \%(14 / 221)\end{array}$ & $\begin{array}{l}\text { RECIST criteria of no or TGR criteria } \\
\text { of liver metastatic sites; }>2 \\
\text { metastatic sites prior to } \\
\text { immunotherapy }\end{array}$ & $\begin{array}{l}\text { OS: } 5.23 \text { months vs. } 7.33 \\
\text { months, } P=0.04 \text {, by } \\
\text { RECIST; } 4.2 \text { months vs. } \\
6.27 \text { months, } P=0.346 \text {, } \\
\text { by TGR }\end{array}$ & Matos et al. ${ }^{[17]}$ (2020) \\
\hline $\begin{array}{l}\text { Multiple } \\
\text { tumor } \\
\text { types }\end{array}$ & $\begin{array}{l}\text { PD-1 inhibitors } \\
\text { (nivolumab or } \\
\text { pembrolizumab) }\end{array}$ & $\Delta \mathrm{TGR}>50 \%$ & $10.08 \%(38 / 377)$ & $\begin{array}{l}>2 \text { metastatic sites prior to } \\
\text { immunotherapy; ECOG } \geq 2 \text {; hepatic } \\
\text { metastases; serum LDH }>\text { upper } \\
\text { normal limit; KRAS status in } \\
\text { colorectal cancer }\end{array}$ & $\begin{array}{l}\text { OS: } 3.6 \text { months vs. } 7.3 \\
\text { months, } P<0.01\end{array}$ & Chen et al. ${ }^{[20]}(2021)$ \\
\hline $\begin{array}{l}\text { Multiple } \\
\text { tumor } \\
\text { types }\end{array}$ & $\begin{array}{l}\text { PD-1 or PD-L1 inhibitor } \\
\text { monotherapy or } \\
\text { combined with CTLA-4 } \\
\text { inhibitor }\end{array}$ & $\begin{array}{l}4 \text { categories (TGR, TGK, early tumor burden } \\
\text { increase, or combinations of the above) }\end{array}$ & $5.9 \%-43.1 \%(3109)$ & - & - & Park et al. ${ }^{[22]}(2021)$ \\
\hline NSCLC & $\begin{array}{l}\text { PD-1 or PD-L1 inhibitor } \\
\text { monotherapy or } \\
\text { combined with CTLA-4 } \\
\text { inhibitor }\end{array}$ & RECIST 1.1 progression and $\Delta \mathrm{TGR}>50 \%$ & $\begin{array}{l}14 \%(56 / 406 \text { treated } \\
\text { with } \mathrm{ICI}) ; 5 \%(3 / 59 \\
\text { treated with } \\
\text { chemotherapy) }\end{array}$ & $\begin{array}{l}>2 \text { metastatic sites prior to } \\
\text { immunotherapy }\end{array}$ & $\begin{array}{l}\mathrm{OS}: \mathrm{HR}=2.18,95 \% \mathrm{Cl} \\
1.29-3.69, P=0.03\end{array}$ & Ferrara et al..$^{[9]}(2018)$ \\
\hline NSCLC & $\begin{array}{l}\text { PD-1 inhibitors } \\
\text { (nivolumab) }\end{array}$ & $<3$ nivolumab injections & $20 \%(57 / 292)$ & PS $>2$ at nivolumab initiation & $\begin{array}{l}\text { OS: } 1.4 \text { months vs. } 13.5 \\
\text { months, } P<0.0001\end{array}$ & Costantini et al..$^{[12]}(2019)$ \\
\hline NSCLC & $\begin{array}{l}\text { PD-1 or PD-L1 inhibitor } \\
\text { monotherapy }\end{array}$ & $\begin{array}{l}\text { Volumetric time-dependent criteria ( }(T G K \geq 2 \text { ) or } \\
\text { one-dimensional criteria: RECIST } 1.1 \text { progression }\end{array}$ & $\begin{array}{l}14.3 \% \text { ( } 48 / 335 \text { by } \\
\text { volumetric assessment); } \\
13.1 \% \text { ( } 44 / 335 \text { by one- } \\
\text { dimensional criteria) }\end{array}$ & $\begin{array}{l}\text { High neutrophil-to-lymphocyte } \\
\text { ratio; LKB1 mutation }\end{array}$ & $\begin{array}{l}\text { OS: } 4.7 \text { months vs. } 7.9 \\
\text { months, } P=0.009, \text { by } \\
\text { volumetric; } 5.2 \text { months } \\
\text { vs. } 7.1 \text { months, } P= \\
0.288, \text { by RECIST }\end{array}$ & Kim et al. ${ }^{[14]}(2020)$ \\
\hline NSCLC & $\begin{array}{l}\text { PD-1 or PD-L1 inhibitor } \\
\text { monotherapy }\end{array}$ & $\mathrm{TGK} \geq 2, \mathrm{TGR} \geq 2$, or TTF $<2$ months & $\begin{array}{l}20.9 \%(55 / 263 \text { TGK), } \\
20.5 \%(54 / 263 \text { TGR }) \\
37.3 \%(98 / 263 \text { TTF })\end{array}$ & $\begin{array}{l}\geq 2 \text { metastatic locations; liver } \\
\text { metastases; neutrophils; neutrophil- } \\
\text { to-lymphocyte ratio; LDH; high } \\
\text { CD8 }^{+} \text {PD-1 } 1^{+} \text {TIGIT } \\
\text { CCR7 cells; low CD8 } 8^{+} \\
\text {CDRA T cells }\end{array}$ & $\begin{array}{l}\text { PFS: } \mathrm{HR}=4.62,95 \% \mathrm{Cl}: \\
2.87-7.44, P<0.05 ; \mathrm{OS}: \\
\mathrm{HR}=5.71,95 \% \mathrm{Cl}: 3.14- \\
8.23, P<0.05\end{array}$ & Kim et al. ${ }^{[23]}(2019)$ \\
\hline NSCLC & $\begin{array}{l}\text { PD-1 inhibitors } \\
\text { (nivolumab) }\end{array}$ & RECIST 1.1 progression and TGR $\geq 2$ & $19.2 \%(16 / 83)$ & $\begin{array}{l}\text { Pleura or pericardium metastasis; } \\
\text { low circulating albumin }\end{array}$ & $\begin{array}{l}\text { PFS: } 0.43 \text { months vs. } \\
1.35 \text { months; OS: } 2.2 \\
\text { months vs. } 4.1 \text { months }\end{array}$ & Kim et al. ${ }^{[24]}(2020)$ \\
\hline NSCLC & $\begin{array}{l}\text { PD-1/PD-L1 inhibitor } \\
\text { monotherapy or } \\
\text { combined with other }\end{array}$ & $\begin{array}{l}\text { Ferté criteria (RECIST } 1.1 \text { progression and TGR } \geq 2 \text { ), } \\
\text { Le Tourneau criteria }(T G K>2 \text { ), Garralda criteria } \\
\text { (increase of } \geq 20 \% \text { in target tumor burden plus }\end{array}$ & $5.4 \%-18.5 \%(406)$ & $\begin{array}{l}\text { No (including previously described } \\
\text { prognostic factors such as age, } \\
\text { LDH, albumin, }>2 \text { metastatic sites, }\end{array}$ & - & Kas et al. ${ }^{[15]}(2020)$ \\
\hline
\end{tabular}


immunotherapy treatments

multiple new lesions or increase of $\geq 40 \%$ in target umor burden compared with baseline) or Caramella

NSCLC PD-1/PD-L1 inhibito monotherapy or combined with other immunotherapy

treatments

NSCLC PD-1 or PD-L1 inhibitor monotherapy or

combined with CTLA-4 inhibitor

NSCLC PD-1 or PD-L1 inhibitor monotherapy

NSCLC PD-1/PD-L1 inhibitor monotherapy or combined with chemotherapy

NSCLC PD-1 or PD-L1 inhibitor monotherapy

HNSCC PD-1 or PD-L1 inhibitor monotherapy or combined with CTLA-4 inhibitor

HNSCC PD-1 or PD-L1 inhibitor

TGK $\geq 2$ monotherapy or combined with CTLA-4 inhibitor

MM PD-1 inhibitor, CTLA-4 inhibitor monotherapy or >
PD-1 inhibitors
$\mathrm{TGK} \geq 2$ and $\left(\mathrm{S}_{\text {POST }} / \mathrm{S}_{0}-1\right)>0.5$ (nivolumab) $>2$

$T G K>2$ and TTF $\leq 2$ months

$\mathrm{TGR}>2$

$\mathrm{TGK} \geq 2$

TGK $>2$

TGK $>4$ and $\Delta \mathrm{TGR}>40 \%$

PD-1 inhibitors (nivolumab)

RCC and PD-1/PD-L1 inhibitor monotherapy
Tumor burden increase $\geq 50 \%$, TGR $\geq 2$, or $\geq 10$ metastatic sites

RMH score)

$8.02 \%-30.43 \%(1389)$

upper Normal limit; $>2$ metastatic

sites prior to immunotherapy; liver

metastases

$11.3 \%, 5.7 \%, 17 \%, 9.6 \%$, -

$31.7 \%(169)$

$11.3 \%(26 / 231)$

$17.6 \%(25 / 142$

monotherapy); $2.9 \%$

(1/34 combinatio

therapy)

$8.1 \%(6 / 74)$

$14.4 \%(18 / 125)$

$3 \%(1 / 75)$

$22.1 \%(143)$

$12.7 \%(24 / 189)$

$0.9 \%(1 / 102), 11.9 \%$

$(12 / 101)$
Heavy smoker; PD-L1 expression $\leq$ $1 \% ; \geq 3$ metastatic sites

$\mathrm{CD} 4^{+} \mathrm{CD} 25^{+} \mathrm{CD} 127^{10} \mathrm{FoxP3}^{+}$Treg cells was increased on Day 7 after initiation of treatment

Younger age; primary tumor of or cavity; previous locoregional irradiation

Primary site in the oral cavity; administration of $\mathrm{ICl}$ in the second/third setting

PD-L1CPS; MMR

utrophil-to-lymphocyte ratio

C; creatinine $>1.2 \mathrm{mg} / \mathrm{dL}$
Chen et al. ${ }^{[26]}(2020)$

Abbar et al. ${ }^{[19]}(2021)$

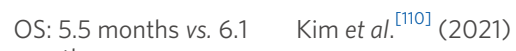
month

$$
\text { Matsuo et al. }{ }^{[113]} \text { (2021) }
$$$$
\text { Kang et al. }{ }^{[25]} \text { (2021) }
$$

PFS: 1.2 months vs. 3.4 Park et al..$^{[31]}$ (2020) months, $P<0.001$; OS:

3.4 months vs. 10.7

months, $P=0.047$

PFS: 1.8 months vs. $6.1 \quad$ Economopoulou et al. ${ }^{[51]}$

months, $P=0.0001:$ OS: (2021)

6.53 months vs. 15

months, $P=0.0018$

Schuiveling et al. ${ }^{[114]}$ (2021)

PFS: 1.2 months vs. $1.7 \quad$ Hagi et al. ${ }^{[115]}$ (2020)

months, $P<0.001$; OS

3.3 months vs. 6.8

months, $P=0.012$

PFS: $\mathrm{HR}=2.194,95 \% \mathrm{Cl}:$ Kim et al ${ }^{[116]}(2021)$

1.214-3.964; OS: $\mathrm{HR}=$

$2.238,95 \% \mathrm{Cl}: 1.233$

4.062

PFS: 1.3 months vs. 3.9 Hwang et al. ${ }^{[117]}$ (2020) months, $P<0.001$; OS

3.5 months vs. 7.3

months, $P<0.001$ 
PFS: Progression-free survival; OS: overall survival; NSCLC: non-small-cell carcinoma; HNSCC: head and neck squamous cell carcinoma; MM: malignant melanoma; GC: gastric cancer; HCC: hepatocellular carcinoma; RCC: renal cell carcinoma; UC: urothelial carcinoma; GYN: gynecological malignancies; PD-1/PD-L1: programmed cell death-1/programmed cell death-ligand 1; LDH: lactic dehydrogenase; RMH: Royal Marsden Hospital score; RECIST: Response Evaluation Criteria in Solid Tumors; TGR: tumor growth rate; $\triangle T$ TGR: the difference of TGR before and during immunotherapy; TGK: tumor growth kinetics; TTF: time to treatment failure; ECOG: Eastern Cooperative Oncology Group; KRAS: Kirsten rat sarcoma viral oncogene homolog; CPS: combined positive score of PD-L1 expression; MMR: mismatch repair.

\section{CASE SUMMARY}

The limitations of ICIs, as they may not be appropriate for some patients, caused "disease flare" in a 54-year-old man with stage IIB lung adenocarcinoma after 10th-line treatment with nivolumab ${ }^{[27]}$. This case opened up the HPD patient reports, and, according to incomplete statistical data, in 44 cases involving 53 patients, malignant tumor types were mainly distributed in the respiratory system, digestive system, and urinary system and were immune to single and double drugs to a significantly higher degree than due to the immune or anti-angiogenesis drugs with combination chemotherapy. Most patients with HPD after ICI treatment developed liver, lung, and brain metastases. Selected case studies are listed in Table 2. Among them, the youngest patient was a 13-year-old girl suffering from malignant melanoma, which progressed to HPD mode after two cycles of treatment with avelumab in palliative radiotherapy. The Food and Drug Administration has approved ICIs for the treatment of children with microsatellite unstable malignant tumors based on reports in adults ${ }^{[28]}$. However, the interaction between children's immune systems and anti-PD1 therapy remains unclear. The oldest patient was an 80-year-old patient with lung squamous carcinoma $^{[29]}$. The symptoms of HPD were pneumonia, pleural effusion, and pericardial effusion. Many patients developed the same symptoms after ICI treatment for malignant tumors of the respiratory system and digestive system and malignant melanoma. A previous study in South Korea reported a higher frequency of increased fluid accumulation in HPD patients with pleural or pericardial metastases after treatment with nivolumab as compared to the progressive disease (PD) patients without HPD [90\% (9/10) vs. 28.6\% (4/14); $P=0.005]$; the circulating albumin level was significantly reduced in HPD patients $(P=0.030)^{[24]}$. A considerable proportion of HPD occurred in patients after radiotherapy, which suggested that radiotherapy had a bidirectional regulatory effect on the anti-tumor immune response. If the immunosuppressive function of radiotherapy is dominant, a combination of ICIs may lead to $\mathrm{HPD}^{[30]}$. A clinical study of head and neck squamous cell carcinoma also suggested that previous local irradiation was an important predictor of HPD ${ }^{[31]}$. In addition to being associated with radiotherapy, AKT1 E17K mutation ${ }^{[32]}$ and PI3K/AKT pathway ${ }^{[33]}$ were also related to HPD. Interestingly, after immunohistochemical staining of the primary tumor and metastases samples with HPD, Barham et al. ${ }^{[34]}$ showed that the tumor infiltrating lymphocyte (TIL) number was not necessarily correlated with ICI response, as levels of granzyme B and TIA-1 of infiltrated CD ${ }^{+} \mathrm{T}$ cells were mostly negative, indicating that these were inflammatory $\mathrm{T}$ cells which cause tumor drug resistance and myocarditis. They cannot effectively dissolve the tumor, so additional functional markers are required to distinguish between inflammatory and cytolytic CD $8^{+}$TIL. For treatment, the salvage therapy in HPD has not been limited to chemotherapy. A patient with lung adenocarcinoma developed HPD with rib metastasis shortly after ICI-based combination therapy, and the lesion was significantly reduced after implantation of $\mathrm{I}^{125}$ particles into the chest wall ${ }^{[35]}$. Another patient with lung adenocarcinoma showed MET amplification on re-biopsy after HPD and remission occurred with a c-MET inhibitor ${ }^{[36]}$. A patient with triple-negative breast cancer showed HPD after pembrolizumab treatment combined with chemotherapy and remission with atezolizumab administration combined with chemotherapy ${ }^{[37]}$. A patient with cardiac cancer was in remission after salvage 
Table 2. Cases summary on hyper-progression after immunotherapy

\begin{tabular}{|c|c|c|c|c|c|c|c|}
\hline $\begin{array}{l}\text { Tumor } \\
\text { type }\end{array}$ & Gender & $\begin{array}{l}\text { Age } \\
\text { (years) }\end{array}$ & Agents & $\begin{array}{l}\text { Radiotherapy } \\
\text { before ICls }\end{array}$ & Clinical symptoms & Progressive organ & Ref. \\
\hline$\overline{S C L C}$ & Male & 35 & Nivolumab & No & Pleural effusion & Chest wall & $\begin{array}{l}\text { Chiba et al. }{ }^{[119]} \\
(2020)\end{array}$ \\
\hline LUSC & Male, Male & 69,80 & Nivolumab & No & $\begin{array}{l}\text { Pneumonia, pleural } \\
\text { effusion, pericardial } \\
\text { effusion }\end{array}$ & Lung & $\begin{array}{l}\text { Kanazu et al. }{ }^{[29]} \\
(2018)\end{array}$ \\
\hline LUAD & Female & 66 & Pembrolizumab & Yes & $\begin{array}{l}\text { Pleural effusion, } \\
\text { pericardial effusion }\end{array}$ & Brain, lung & $\begin{array}{l}\text { Fricke et al. }{ }^{[120]} \\
(2020)\end{array}$ \\
\hline LUAD & Male & 68 & Nivolumab & No & Jaundice, fever & Liver, pancreas & $\begin{array}{l}\text { Martorana et al. }{ }^{[121]} \\
(2021)\end{array}$ \\
\hline LUAD & Female & 63 & Sintilimab & Yes & $\begin{array}{l}\text { Abdominal distension, } \\
\text { poor appetite }\end{array}$ & Liver, pancreas & Lin et al..$^{[122]}(2020)$ \\
\hline LUAD & Male & 65 & $\begin{array}{l}\text { Pembrolizumab and paclitaxel liposome (salvage treatment: } \\
\text { c-Met inhibitor) }\end{array}$ & Yes & - & Brain, lung & Peng et al. ${ }^{[36]}$ (2020) \\
\hline LPC & Male & 66 & Atezolizumab & Yes & $\begin{array}{l}\text { Pericardial effusion, } \\
\text { pericarditis, pleural } \\
\text { effusion }\end{array}$ & Lung, brain, liver, diaphragm & Oguri et al. ${ }^{[123]}(2021)$ \\
\hline ESCC & Male & 40 & Camrelizumab & No & - & Liver & $\begin{array}{l}\text { Wang et al. }{ }^{[124]} \\
(2020)\end{array}$ \\
\hline GC & Male & 36 & Nivolumab (salvage treatment: capecitabine and pyrotinib) & No & - & Lung, liver & $\begin{array}{l}\text { Huang et al. }{ }^{[125]} \\
\text { (2019) }\end{array}$ \\
\hline AEG & Female & 56 & $\begin{array}{l}\text { Pembrolizumab (salvage treatment: paclitaxel and } \\
\text { ramucirumab) }\end{array}$ & No & - & $\begin{array}{l}\text { Lung, spine, ilium, retroperitoneal } \\
\text { lymph node, etc. }\end{array}$ & Sama et al. ${ }^{[38]}$ (2019) \\
\hline $\mathrm{HCC}$ & Male & 36 & Atezolizumab and bevacizumab & No & Abdominal pain & Liver & Singh et al. ${ }^{[126]}(2021)$ \\
\hline $\mathrm{HCC}$ & Male/Male/Male & $69 / 72 / 69$ & Tremelimumab/nivolumab/tremelimumab and durvalumab & No/TARE/TARE & - & $\begin{array}{l}\text { Liver, portal vein } \\
\text { thrombosis/lung, } \\
\text { peritoneum/liver, lung }\end{array}$ & $\begin{array}{l}\text { Wong et al. }{ }^{[127]} \\
(2019)\end{array}$ \\
\hline COAD & Female & 48 & Pembrolizumab & No & Fatigue & Liver, retroperitoneal lymph node & Chan et al..$^{[128]}$ (2020) \\
\hline CMM & Female & 25 & Nivolumab & Yes & $\begin{array}{l}\text { Ascites, pleural effusion, } \\
\text { epilepsy }\end{array}$ & Peritoneum, pleura, brain & $\begin{array}{l}\text { Yilmaz et al. }{ }^{[129]} \\
(2019)\end{array}$ \\
\hline AMM & Female & 49 & $\begin{array}{l}\text { Ipilimumab and nivolumab (salvage treatment: } \\
\text { chemotherapy)? }\end{array}$ & No & - & Lung, brain & $\begin{array}{l}\text { Forschner et al. }{ }^{[130]} \\
(2017)\end{array}$ \\
\hline MMM & Female & 79 & Ipilimumab and nivolumab & Yes & $\begin{array}{l}\text { Fulminant myocarditis, } \\
\text { ascites, dizzy }\end{array}$ & Lung, peritoneum & $\begin{array}{l}\text { Barham et al. } \\
(2021)\end{array}$ \\
\hline MM & Female & 13 & Nivolumab & Yes & - & Multiple organs & Vaca et al. ${ }^{[28]}(2019)$ \\
\hline IBC & Male & 78 & Nivolumab & Yes & - & Sternum, liver & $\begin{array}{l}\text { Koukourakis et al. }{ }^{[131]} \\
(2020)\end{array}$ \\
\hline KIRC & Female & 42 & Nivolumab & Yes & Arthritis of hand and knee & Lung & Liu et al. ${ }^{[30]}(2021)$ \\
\hline
\end{tabular}




\begin{tabular}{|c|c|c|c|c|c|c|c|}
\hline $\mathrm{mUC}$ & Male & 57 & Anti-PD-L1 and immune checkpoint modulator & No & - & Liver, brain & $\begin{array}{l}\text { Grecea et al. }{ }^{[132]} \\
(2020)\end{array}$ \\
\hline CSEC & Female & 46 & Pembrolizumab & Yes & Biliary obstruction & Liver & Lin et al. ${ }^{[122]}(2020)$ \\
\hline sccc & Female & 49 & Pembrolizumab & No & - & Lung & Xu et al. ${ }^{[32]}(2019)$ \\
\hline PM & Male & 75 & Nivolumab & No & Abdominal distension & Liver & $\begin{array}{l}\text { Ikushima et al. }{ }^{[133]} \\
(2020)\end{array}$ \\
\hline TNBC & Female & 67 & $\begin{array}{l}\text { Pembrolizumab and gemcitabine (salvage treatment: } \\
\text { atezolizumab and nab-paclitaxel) }\end{array}$ & No & $\begin{array}{l}\text { Fatigue, poor appetite, } \\
\text { abdominal pain }\end{array}$ & Liver & Feng et al. ${ }^{[37]}$ (2021) \\
\hline MSC & Female & 60 & Nivolumab & No & Decreased eyesight & Orbit, brain & $\begin{array}{l}\text { Xiang et al. }{ }^{[134]} \\
(2020)\end{array}$ \\
\hline LS & Male & 63 & Durvalumab and tremelimumab & Yes & - & Liver & Chan et al. ${ }^{[135]}(2020)$ \\
\hline
\end{tabular}

SCLC: Small cell lung cancer; LUSC: lung squamous cell carcinoma; LUAD: lung adenocarcinoma; LPC: lung pleomorphic carcinoma; ESCC: esophageal squamous cell carcinoma; GC: gastric cancer; AEG: adenocarcinoma of esophagogastric junction; HCC: hepatocellular carcinoma; COAD: colon adenocarcinoma; CMM: cutaneous malignant melanoma; AMM: acral malignant melanoma; MMM: mucosal malignant melanoma; MM: malignant melanoma; IBC: invasive bladder cancer; KIRC: kidney renal clear cell carcinoma; mUC: metastatic urothelial cancer; CSEC: cervical squamous epithelium carcinoma; SCCC: small cell carcinoma of cervix; PM: peritoneal mesothelioma; TNBC: triple-negative breast cancer; MSC: maxillary sinus carcinoma; LS: liposarcoma.

therapy with paclitaxel and ramucirumab following $\mathrm{HPD}^{[38]}$.

\section{MOLECULAR MECHANISM UNDERLYING HPD}

The mechanism of action underlying ICI is the removal of the "braking" function of immune checkpoints and reduction in the escape of tumor cells to enhance the anti-tumor immune response of effector $\mathrm{T}$ cells ${ }^{[39]}$. ICIs reverse the immunosuppressive state of $\mathrm{T}$ cells by disrupting the programmed cell death1/programmed cell death-ligand 1 (PD-1/PD-L1) axis ${ }^{[40]}$. However, PD-1 receptors are present not only on the surface of $\mathrm{T}$ cells but also on the surface of many innate or acquired immune cells, including NK cells, monocytes, macrophages, Treg cells, and B cells ${ }^{[41]}$. Furthermore, immune cells have varying impacts on PD-1/PD-L1 axis disruption, boosting or inhibiting immune function. In addition, tumor treatment through ICI intervention may also induce changes in the oncogenic pathways of the tumor cells and result in their rapid proliferation and spread ${ }^{[42]}$. Therefore, HPD may not be triggered by a single factor, but by a series of events that occur simultaneously. Most of the current studies on the molecular mechanisms of HPD focus on the tumor and the tumor microenvironment. In the next sections, we discuss these in detail to facilitate the understanding of the molecular mechanisms underlying ICI-induced HPD. The molecular mechanisms underlying HPD are shown in Table 3.

\section{Alteration in the tumor cell types following ICI}

HPD is a type of primary resistance to immunotherapy, and the mechanism of its occurrence involves alteration in the tumor cell types and the tumor microenvironment. These changes range from enhanced proliferative capacity, invasiveness, and drug resistance of tumor cells to a reduced immunosuppressive capacity in the tumor microenvironment. The tumor cells themselves are altered due to the following reasons: (1) loss of expression of 
Table 3. Mechanisms summary on hyper-progression after immunotherapy

\begin{tabular}{|c|c|c|}
\hline Tumor cells & & Tumor microenvironment \\
\hline \multirow{4}{*}{$\begin{array}{l}\text { 1. Loss of expression of tumor-associated } \\
\text { antigens }{ }^{[43]} \\
\text { 2. Impairment of antigen processing and } \\
\text { delivery } \\
\text { 3. Persistent upregulation of PD-L1 expression on } \\
\text { the surface of tumor cells } \\
\text { 4. Apoptotic resistance in tumor cells }{ }^{[46,47]} \\
\text { 5. Induced dormancy and senescence of tumor } \\
\text { cells } \\
\text { 6. Tumor cells undergo dedifferentiation and } \\
\text { EMT }^{[49]} \\
\text { 7. MDM2/MDM4 amplification and EGFR } \\
\text { mutation }^{[58]}\end{array}$} & Treg cells & $\begin{array}{l}\text { 1. Competition with conventional T cells for IL-2 via Foxp3 }{ }^{[66,136]} \\
\text { 2. Secretion of the anti-inflammatory cytokines TGF } 3, \mathrm{IL}-10 \text {, and IL-35 } \\
\text { 3. The dual expression of CD39 and CD73; the CTLA-4-mediated } \\
\text { downregulation of CD } 80 \text { and CD } 86 \text { on the surface of APCs } s^{[71,73]} \\
\text { 4. Production of FGL2 to suppress CD8 }{ }^{+} \text {T cells and APCs through FcyRIIl }{ }^{[74,137]} \\
\text { 5. Express PD-1 receptors } \\
\text { 6. A spatial ecological niche dedicated to immunosuppression }{ }^{[76]}\end{array}$ \\
\hline & T cells & $\begin{array}{l}\text { 1. Release the cytokines IFN } \gamma^{[80]}, \mathrm{IL}-17^{[86,87]}, \mathrm{IL}-22^{[88,89]}, \mathrm{TNF}^{[90,91]} \text { and IL-6 } \\
\text { 2. The combination of multiple cytokines, such as } \mathrm{TGF}^{[92]} \text { and } \mathrm{TNF} \alpha^{[80]} \text { or IFN } \gamma \text { and } \\
\mathrm{TNF} \alpha^{[93]} \\
\text { 3. The binding of CD } 27 \text { receptor to CD70 ligand }\end{array}$ \\
\hline & B cells & $\begin{array}{l}\text { IgG4 competes with IgG1 to bind to Fc receptors on the surface of immune } \\
\text { effector cells }\end{array}$ \\
\hline & $\begin{array}{l}\text { Fc } \\
\text { receptor }\end{array}$ & The binding of the Fc region of the anti-PD- 1 antibody to the macrophage $F c \gamma R^{[62]}$ \\
\hline
\end{tabular}

tumor-associated antigens ${ }^{[43]}$; (2) impairment of antigen processing and delivery, including the loss of human leukocyte antigen expression, failing to deliver tumor antigens to the cell surface ${ }^{[44]}$; (3) persistent upregulation of PD-L1 expression on the surface of tumor cells, which competes with ICI for binding to $\mathrm{PD}-1$ receptors on the surface of $\mathrm{CD} 8^{+} \mathrm{T}$ cells and inhibits the anti-tumor immune response ${ }^{[45]}$; (4) apoptotic resistance in tumor cells $s^{[46,47]}$; (5) induced dormancy and senescence of tumor cells $s^{[48]}$, whereby the tumor cells are temporally controlled and lay the groundwork for future recurrence and metastasis; and (6) tumor cells undergo dedifferentiation and epithelial to mesenchymal transition (EMT) ${ }^{[4]}$.

\section{MDM2/MDM4 amplification and EGFR mutation}

In 2017, Kato et al. ${ }^{[12]}$ evaluated 155 patients with advanced tumors and found a 3.9\% incidence of HPD. Through Next-Generation Sequencing (NGS), murine double minute 2/4 (MDM2/MDM4) amplification was identified in six patients who had TTF $<2$ months and two patients were diagnosed with HPD; in 10 other patients, epidermal growth factor receptor (EGFR) mutations were identified. By multivariate analysis, it was found that MDM2/MDM4 amplification and EGFR mutations were associated with TTF $<2$ months. The presence of MDM2 amplification and EGFR mutations in patients with HPD were also found in a clinical study by Singavi et al. ${ }^{[50]}$ and Economopoulou et al. ${ }^{[51]}$. The MDM2 protein encoded by the $M D M 2$ gene is a major negative regulator of the p53 protein. MDM2 can ligate to the p53 protein through the E3 ubiquitin ligase, and the ubiquitinated p53 can be transferred to the cytoplasm and targeted for degradation by the proteasome ${ }^{[52]}$. Thus, MDM2 amplification can promote tumorigenesis directly or indirectly through the inhibition of p53. In 2018, Kato et al ${ }^{[53]}$ extended the scope of NGS sequencing to include 102,878 patients with different malignancies and found MDM2 amplification in $3.5 \%$ of patients; this was present in a small proportion of patients in most tumor types, and $97.6 \%$ of these patients had potentially targetable genomic co-alterations, which suggested that appropriately targeted drugs could be designed to target MDM2 amplification-induced HPD. Fang et al. ${ }^{[54]}$ conducted preclinical studies using the MDM2 inhibitor, APG-115. It acts as an indirect p53 activator, suppresses M2 macrophage polarization, and slows tumor invasion and progression, improving anti-tumor immunity to anti-PD-1 treatment. APG115-mediated p53 activation promoted anti-tumor immunity in TME regardless of the Trp53 status of the tumor itself. Sahin et al. ${ }^{[55]}$ also used the MDM2 inhibitor AMG-232 in combination with anti-PD-1 antibody therapy to enhance T cell-mediated killing of tumors regardless of PD-L1 expression. Another MDM2 inhibitor, idasanutlin (RG7388), in combination with cytarabine therapy, is the first to enter phase III clinical trials for $\mathrm{AML}^{[56,57]}$. 
EGFR is the first identified member of the ErbB family and plays an important role in physiological processes, including cell growth, proliferation, and differentiation. EGFR is also involved in tumor development and immunotherapy-related resistance. A meta-analysis involving 21,047 patients from 35 randomized controlled trials indicated that patients with EGFR wild type had significantly prolonged PFS and OS after treatment with ICI, while those with EGFR mutations did not show any improvement ${ }^{[58]}$. This in part reflected the fact that EGFR mutations are a cause of ICI resistance. The TME in EGFR mutated lung adenocarcinoma was non-inflammatory; interestingly, the non-inflammatory TME had a high infiltration of $\mathrm{CD}^{+}$Treg cells. EGFR signaling activates cJun/cJun N-terminal kinase and reduces the level of interferon regulatory factor-1; the former increases CCL22 and thereby recruits CD4 $4^{+}$Treg cells, while the latter reduces the levels of CXCL10 and CCL5 and, in turn, induces $\mathrm{CD}^{+} \mathrm{T}$ cell infiltration ${ }^{[59]}$. In addition, EGFR can upregulate the number of immunosuppressive receptors and induce the secretion of cytokines with immunosuppressive functions [IL-6, IL-10, and transforming growth factor (TGF $\beta$ )] from the TME, which in turn leads to ICI treatment resistance ${ }^{[0]}$. To some extent, this may explain the occurrence of HPD in patients with EGFR mutations after ICI treatment; however, the exact mechanism of induction needs to be further elucidated. Other somatic mutations and carcinogenic pathways exist in addition to MDM2 amplification and EGFR mutations. Xiong et al. ${ }^{[1]]}$ evaluated the mutational and transcriptional characteristics of tumors before and after anti-PD-1 immunotherapy in two patients who acquired HPD. Somatic mutations in recognized cancer genes, including tumor suppressor genes such as TSC2 and VHL, were discovered, as well as transcriptional activation of carcinogenic pathways including IGF-1, ERK/MAPK, PI3K/AKT, and TGFß.

\section{Treg cells}

Treg cells are important for the maintenance of the body's immune tolerance. The majority of $\mathrm{CD} 4^{+}$Treg cells are produced by the thymus, which accounts for $10 \%$ of circulating $\mathrm{CD} 4^{+} \mathrm{T}$ cells. The major transcription factor is Foxp3, which determines the phenotypic and functional characteristics of Treg cells $^{[62]}$. In a normal organism, Treg cells negatively regulate immune cells such as effector $\mathrm{T}$ cells to prevent autoimmune overload, while, in tumors, Treg cells exhibit different biological functions ${ }^{[63]}$. Kang et al ${ }^{[25]}$ found significantly higher FoxP3 $3^{+}$Treg cells in 74 patients with advanced NSCLC who developed HPD and significantly fewer Treg cells in non-HPD patients $(P=0.024)$. Therefore, $\mathrm{PD}-1^{+}$Treg cells could be an effective biomarker for the identification of $\mathrm{HPD}^{[64]}$. Previous studies have shown that high Foxp $3^{+}$Treg cell infiltration in tumors is significantly associated with poorer $\mathrm{OS}^{[65]}$. Foxp3 is a transcriptional repressor of IL-2 that also isolates transcriptional activators acute myeloid leukemia 1 and nuclear factor of activated Tcells outside the nucleus, preventing Treg cells from producing IL-2 ${ }^{[66]}$. However, Tregs and conventional $\mathrm{CD}_{4}{ }^{+} \mathrm{T}$ cells both require IL-2 to survive. As a result, Treg cells compete with conventional T cells for IL-2 via Foxp3 by boosting the expression of CD25 (IL2 $\alpha$ ), leading to the formation of a high-affinity IL-2 receptor (heterotrimeric complex $(\mathrm{IL} 2 \mathrm{R} \alpha \beta \gamma)^{[67]}$.

Treg cells secrete the anti-inflammatory cytokines TGF $\beta$, IL-10, and IL-35 to deplete conventional T cells ${ }^{[6,69]}$. TGF, as a Th1 inhibitor, stimulates the TGF $\beta R I / I I$ receptor on conventional T cells to block IFN $\gamma$ induced Th1 activation by inhibiting the expression of two essential Th1 transcription factors, T-bet and IFN regulatory factor $1^{[70]}$. Indeed, IL- $10^{+}$and IL- $35^{+}$Treg cells account for a large proportion of tumors. Gene profiles of conventional T cells exposed to these Treg subtypes were analyzed, and it was discovered that $\mathrm{T}$ cells depletion was promoted by IL- $35^{+}$Treg, but antitumor effects were inhibited by IL- $10^{+}$Treg ${ }^{[68]}$.

Treg cells, which have the dual expression of CD39 and CD73, block T cell activation by adenosine triphosphate (ATP) and generate adenosine to inhibit T cells. CD39 and CD73, respectively, hydrolyze ATP/ADP to AMP and AMP to adenosine, leading to a large enrichment of adenosine around Treg cells. Adenosine can induce actin cytoskeleton rearrangement and hence function as a chemoattractant for 
dendritic cells (DCs), causing DCs to congregate towards Treg cells ${ }^{[7]}$. Then, with enhanced leukocyte function-associated antigen-1 stability and expression, Treg cells and DCs create a tight aggregate, decreasing the interaction of $\mathrm{T}$ cells to $\mathrm{DCs}^{[72]}$. On the other hand, cytotoxic T-lymphocyte-associated protein 4 (CTLA-4) is mediated by Treg cells, resulting in the downregulation of CD80 and CD86 on the surface of antigen-presenting cells (APCs) to restrict the activation of conventional $\mathrm{T}$ cells ${ }^{[73]}$. However, it is uncertain whether the capacity of Treg cells to control CD80 and CD86 is simply dependent on CTLA-4 expression.

Treg cells produce fibrinogen-like protein 2 (FGL2) to suppress $\mathrm{CD}^{+} \mathrm{T}$ cells and APCs through Fc $\gamma$ RIIb. FGL2 is considered a signaling molecule for Treg cells as Foxp3 in Treg stimulates the expression of $\mathrm{FGL2}^{[74]}$. The major immunomodulatory effect of FGL2 is mediated via Fc $\gamma R$ IIB in APCs. A study has demonstrated that mice lacking the Fc $\gamma$ RIIB receptor develop autoimmune glomerulonephritis ${ }^{[75]}$.

Treg cells can also express PD-1 receptors on their surface, and, although blocking the PD-1/PD-L1 axis activates $\mathrm{T}$ cells, Treg cells are also highly active, immune function is greatly affected, and anti-tumor immune efficacy is reduced. However, highly activated Treg cells in lymphoid organs resist newly generated anti-tumor T cells, leading to a more attenuated anti-tumor immune effect. These result in uncontrolled tumors, which may lead to HPD. In addition, Murakami et al. ${ }^{[76]}$ reported a spatial ecological niche dedicated to immunosuppression which is formed between $\mathrm{CD} 8^{+} \mathrm{CD} 39^{+} \mathrm{PD}-1^{+} \mathrm{T}$ cells and Foxp $3^{+} \mathrm{PD}-1^{+}$Treg cells due to potential interactions between these cells in close proximity following PD-1 blockade in renal cancer. The shift to an immunosuppressive environment is more pronounced in metastatic foci. Anti-CD25 and PD-1 bispecific antibodies are currently used for treatment to deplete Treg cells. Subsequent treatment with anti-PD-1 antibodies may only enhance conventional $\mathrm{T}$ cells and $\mathrm{CD}^{+} \mathrm{T}$ cells $\mathrm{s}^{[77]}$. Alternatively, adenosine, a product of Treg cells, could be inhibited by combining the anti-PD-1 antibody with adenosine deaminase for its degradation to inosine, thereby reducing cAMP production to weaken the inhibition of conventional $\mathrm{T}$ cells and enhance anti-tumor immunity ${ }^{[62]}$. The possibility of interfering with the systemic immune system is considerably minimized by precisely destroying Treg cells around tumor cells.

\section{T cells}

The function of $\mathrm{T}$ cell adaptive immunity is to eliminate tumor cells that positively express antigens ${ }^{[78]}$. However, ICI-enhanced T cell adaptive immune response cannot completely kill tumor cells, as reported in most clinical trials. Even after ICI treatment, adaptive immunity can promote tumor growth directly or indirectly. As a consequence, some researchers believe that enhanced tumor adaptive immune response may be the root cause of HPD in tumor patients after ICI treatment ${ }^{[42]}$. T cell immune response can induce changes in gene expression of tumor cells, such as a downregulation of tumor surface antigens ${ }^{[79]}$ and upregulation of other immune checkpoint ligands ${ }^{[4]}$. However, the underlying mechanism of $\mathrm{T}$ cell immune response leading to changes in tumor cells remains changes in tumor cells are still not clear.

The cytokine IFN $\gamma$ released by T cells may explain a part of the problem. IFN $\gamma$, a common cytokine, is involved in several cellular changes, including EMT induction ${ }^{[80]}$. EMT in tumor cells is related to the upregulation of inhibitory checkpoint ligands ${ }^{[8]]}$, resistance to cell-mediated cytotoxicity ${ }^{[82]}$, and the production of immunosuppressive effects ${ }^{[83]}$. Furthermore, IFN $\gamma$ has the ability to upregulate immune checkpoint ligands ${ }^{[84]}$, inducing tumor cell dormancy, apoptosis ${ }^{[84]}$, and hyperplasia.

The same cytokine can play different roles in different environments, depending on the length of time it acts on tumor cells. For instance, prolonged exposure to IFN $\gamma$ and low levels of the cytokine have been demonstrated to have pro-tumorigenic effects ${ }^{[85]}$. Other cytokines, such as IL-1 $17^{[8,87]}$, IL-22 $2^{[88,89]}$, tumor 
necrosis factor $\alpha(\mathrm{TNF} \alpha)^{[0,91]}$, and IL-6 $6^{[92]}$, are involved in tumor promotion. The combination of multiple cytokines may have a greater tumor-promoting effect than a single cytokine; for example, TGF $\beta 1$ leads to demethylation of PD-L1 promoter and TNF $\alpha$ leads to the expression of demethylated promoter and coinduces the overexpression of PD-L1 ${ }^{[80]}$. IFN $\gamma$ and TNF $\alpha$ can co-induce dormancy in tumor cells to promote carcinogenesis $^{[93]}$. However, there is no clear answer as to which $\mathrm{T}$ cell subsets are mainly responsible for the release of these cytokines.

In addition to cytokines, some studies report that the binding of CD27 receptor to CD70 ligand can directly promote proliferation and differentiation of tumor stem cells $s^{[94]}$ or $\mathrm{T}$ cell exosomes to induce EMT and lead to rapid tumor progression ${ }^{[95]}$. Many $\mathrm{T}$ cell subsets are involved, including $\mathrm{CD} 4^{+} \mathrm{T}$ cells ${ }^{[96,97]}, \mathrm{CD}^{+} \mathrm{T}$ cells $^{[8,99]]}$, Th1 cells ${ }^{[100]}$, Th2 cells ${ }^{[101]}$, Th17 cells $^{[102]}$, and Th22 cells $^{[89]}$. However, the proportion and spatial distribution of tumor cells and effective infiltration of immune cells may be the watershed response of adaptive immunity when the tumor-immunity balance is broken.

Although there are few studies on non-Treg $\mathrm{CD} 4^{+} \mathrm{T}$ lymphocytes, after ICI treatment, their levels may show an unexpected increase, which can contribute to the occurrence and development of HPD. A prospective study by Arasanz et al.$^{[103]}$ included 70 patients with advanced NSCLC who underwent ICI treatment. Early detection of HPD in NSCLC by monitoring T cell dynamics showed a strong expansion of highly differentiated $\mathrm{CD} 28^{-} \mathrm{CD} 4^{+} \mathrm{T}$ lymphocytes (CD4 ${ }^{+} \mathrm{THD}$ ) between the first and second treatment cycles in HPD patients and a significant stratification among HPD patients, non-HDP patients, and effective patients (median 1.525, 1.000, and 0.9700, respectively, $P=0.0007$ ). As a consequence, the strong expansion of $\mathrm{CD} 28^{-} \mathrm{CD}^{+} \mathrm{T}$ lymphocytes in peripheral blood during the first treatment cycle could provide an early differential feature of HPD induced by ICI in the treatment of NSCLC. These studies suggest that $\mathrm{CD} 8^{+} \mathrm{T}$ cells and Treg cells are involved in the occurrence and development of HPD in TME. However, several innate and adaptive immune cells may be swept into this storm.

\section{B cells}

PD-1 can also be expressed on the surface of B cells. Some studies have pointed out that anti-PD-1 antibodies can increase the activation, proliferation, and production of inflammatory cytokines in $B$ cells ${ }^{[104]}$. However, follow-up studies show that the loss of B cells does not seem to have any effect on the efficacy of ICI treatment ${ }^{[105]}$. The reason for these differences may be due to the existence of different subsets of B cells. The balance among different B cells (resting B cells, activated B cells, Bregs, and other differentiated $\mathrm{B}$ cells) determines the ultimate role of B cells in tumor immunity ${ }^{[106]}$. Humoral immunity may play a role in carcinogenesis. Wang et al. ${ }^{[107]}$ studied the distribution and mechanism of IgG4 secreted by $\mathrm{B}$ cells in the tumor model and found that the increase in B lymphocytes containing IgG4 in cancer tissues and the increase in IgG4 concentration in serum were highly correlated with the poor prognoses of patients with esophageal cancer. Using a mouse model, it was verified that IgG4 competes with IgG1 to bind to $\mathrm{FC}$ receptors on the surface of immune effector cells and suppresses classical immune responses such as antibody-dependent cytotoxicity (ADCC), antibody-dependent phagocytosis, and complement-dependent cytotoxicity. Thus, tumor cell growth was indirectly promoted. Interestingly, nivolumab is essentially IgG4 with a stable $\mathrm{S} 228 \mathrm{P}$ mutation and significantly promotes the growth of tumors in mice. However, there are only a few studies on the mechanism of B cells participating in HPD after ICI treatment, and these need further validation.

\section{Fc receptor}

The binding of the Fc region of the anti-PD-1 antibody to the macrophage Fc $\gamma \mathrm{R}$ consumes M1 macrophages and stimulates their differentiation to M2-like form. This is another clear mechanism of HPD after ICI treatment in addition to Treg cell-mediated inhibition of anti-tumor immunity leading to $\mathrm{HPD}^{[62]}$. The 
antibody consists of $\mathrm{F}(\mathrm{ab})_{2}$, segment bound to the antigen and $\mathrm{Fc}$ region bound to $\mathrm{Fc} \gamma \mathrm{R}$ on the surface of immune cells. The binding of the $\mathrm{Fc}$ region of IgG antibody to macrophage Fc $\gamma \mathrm{R}$ triggers the ADCC effect, consumes M1 macrophages and NK cells, and reduces the anti-tumor immune effect ${ }^{[107,108]}$. Other studies have shown that many M2-PD-L1 ${ }^{+}$macrophages were observed in the tumor tissues of NSCLC patients with HPD, which could deplete ICI through Fc-Fc $\gamma \mathrm{R}$ interaction, induce M2-like differentiation of macrophages, and secrete IL-10 to mediate the HPD occurrence ${ }^{[109,110]}$. The removal of ICI in the Fc region or knockout of Fc $\gamma \mathrm{R}$ on the surface of macrophages may be a potential research direction for further improvement ${ }^{[111]}$.

\section{CONCLUSION}

HPD occurrence is currently a limitation of ICI treatment and represents the storm-like progression of tumors after ICI administration. The mechanism of HPD is similar to a "tug-of-war" between tumor and anti-tumor effects. Intervention through ICI breaks this balance. It leads to the occurrence of HPD if tumor cells are activated and the anti-tumor effect is inhibited. The side effects of chemotherapy cannot be ignored, although the present incidence of HPD in immune combined chemotherapy has been reduced. One day, we hope to usher in the era of "de-chemotherapy". Then, it would be necessary to face the problem of HPD due to ICI. Hence, the review provides a significant understanding of the current underlying mechanisms for HPD.

\section{DECLARATIONS}

Acknowledgments

We thank the editors and the reviewers for their useful feedback that improved this paper.

\section{Authors' contributions}

Contributed to the conception of the study: Dong X

Wrote the manuscript: Ding P, Wen L

Helped perform the analysis with constructive discussions: Tong F, Zhang R, Huang Y

All authors reviewed and approved the final report.

\section{Availability of data and materials}

Not applicable.

\section{Financial support and sponsorship}

None.

\section{Conflicts of interest}

All authors declared that there are no conflicts of interest.

\section{Ethical approval and consent to participate}

Not applicable.

\section{Consent for publication}

Not applicable.

\section{Copyright}

(c) The Author(s) 2022. 


\section{REFERENCES}

1. Lahmar J, Mezquita L, Koscielny S, et al. Immune checkpoint inhibitors (IC) induce paradoxical progression in a subset of non-small cell lung cancer (NSCLC). Ann Oncol 2016;27:vi423. DOI

2. Champiat S, Dercle L, Ammari S, et al. Hyperprogressive disease is a new pattern of progression in cancer patients treated by antiPD-1/PD-L1. Clin Cancer Res 2017;23:1920-8. DOI PubMed

3. Socinski M, Creelan B, Horn L, et al. NSCLC, metastatic CheckMate 026: a phase 3 trial of nivolumab vs investigator's choice (IC) of platinum-based doublet chemotherapy (PT-DC) as first-line therapy for stage iv/recurrent programmed death ligand 1 (PD-L1)positive NSCLC. Ann Oncol 2016;27:vi577. DOI

4. Peters S, Cappuzzo F, Horn L, et al. OA03.05 analysis of early survival in patients with advanced non-squamous NSCLC treated with nivolumab vs docetaxel in CheckMate 057. J Thorac Oncol 2017;12:S253. DOI

5. Reck M, Schenker M, Lee KH, et al. Nivolumab plus ipilimumab versus chemotherapy as first-line treatment in advanced non-smallcell lung cancer with high tumour mutational burden: patient-reported outcomes results from the randomised, open-label, phase III CheckMate 227 trial. Eur J Cancer 2019;116:137-47. DOI PubMed

6. Ferris RL, Blumenschein G Jr, Fayette J, et al. Nivolumab vs investigator's choice in recurrent or metastatic squamous cell carcinoma of the head and neck: 2-year long-term survival update of CheckMate 141 with analyses by tumor PD-L1 expression. Oral Oncol 2018;81:45-51. DOI PubMed PMC

7. Fradet Y, Bellmunt J, Vaughn DJ, et al. Randomized phase III KEYNOTE-045 trial of pembrolizumab versus paclitaxel, docetaxel, or vinflunine in recurrent advanced urothelial cancer: results of $>2$ years of follow-up. Ann Oncol 2019;30:970-6. DOI PubMed PMC

8. Powles T, Durán I, van der Heijden MS, et al. Atezolizumab versus chemotherapy in patients with platinum-treated locally advanced or metastatic urothelial carcinoma (IMvigor211): a multicentre, open-label, phase 3 randomised controlled trial. Lancet 2018;391:748-57. DOI PubMed

9. Ferrara R, Mezquita L, Texier M, et al. Hyperprogressive disease in patients with advanced non-small cell lung cancer treated with PD-1/PD-L1 inhibitors or with single-agent chemotherapy. JAMA Oncol 2018;4:1543-52. DOI PubMed PMC

10. Mellema WW, Burgers SA, Smit EF. Tumor flare after start of RAF inhibition in KRAS mutated NSCLC: a case report. Lung Cancer 2015;87:201-3. DOI PubMed

11. Aoki M, Shoji H, Nagashima K, et al. Hyperprogressive disease during nivolumab or irinotecan treatment in patients with advanced gastric cancer. ESMO Open 2019;4:e000488. DOI PubMed PMC

12. Kato S, Goodman A, Walavalkar V, Barkauskas DA, Sharabi A, Kurzrock R. Hyperprogressors after immunotherapy: analysis of genomic alterations associated with accelerated growth rate. Clin Cancer Res 2017;23:4242-50. DOI PubMed PMC

13. Saâda-Bouzid E, Defaucheux C, Karabajakian A, et al. Hyperprogression during anti-PD-1/PD-L1 therapy in patients with recurrent and/or metastatic head and neck squamous cell carcinoma. Ann Oncol 2017;28:1605-11. DOI PubMed

14. Kim Y, Kim CH, Lee HY, et al. Comprehensive clinical and genetic characterization of hyperprogression based on volumetry in advanced non-small cell lung cancer treated with immune checkpoint inhibitor. J Thorac Oncol 2019;14:1608-18. DOI PubMed

15. Kas B, Talbot H, Ferrara R, et al. Clarification of definitions of hyperprogressive disease during immunotherapy for non-small cell lung cancer. JAMA Oncol 2020;6:1039-46. DOI PubMed PMC

16. Matos I, Martin-liberal J, Hierro C, et al. Incidence and clinical implications of a new definition of hyperprogression (HPD) with immune checkpoint inhibitors (ICIs) in patients treated in phase 1 (Ph1) trials. JCO 2018;36:3032. DOI

17. Matos I, Martin-Liberal J, García-Ruiz A, et al. Capturing hyperprogressive disease with immune-checkpoint inhibitors using RECIST 1.1 criteria. Clin Cancer Res 2020;26:1846-55. DOI PubMed

18. Gomes da Morais AL, de Miguel M, Cardenas JM, Calvo E. Comparison of radiological criteria for hyperprogressive disease in response to immunotherapy. Cancer Treat Rev 2020;91:102116. DOI PubMed

19. Abbar B, De Castelbajac V, Gougis P, et al. Definitions, outcomes, and management of hyperprogression in patients with non-smallcell lung cancer treated with immune checkpoint inhibitors. Lung Cancer 2021;152:109-18. DOI PubMed

20. Chen S, Gou M, Yan H, et al. Hyperprogressive disease caused by PD-1 inhibitors for the treatment of pan-cancer. Dis Markers 2021;2021:6639366. DOI PubMed PMC

21. Kim JY, Lee KH, Kang J, et al. Hyperprogressive disease during anti-PD-1 (PDCD1) / PD-L1 (CD274) therapy: a systematic review and meta-analysis. Cancers (Basel) 2019;11:1699. DOI PubMed PMC

22. Park HJ, Kim KW, Won SE, et al. Definition, incidence, and challenges for assessment of hyperprogressive disease during cancer treatment with immune checkpoint inhibitors: a systematic review and meta-analysis. JAMA Netw Open 2021;4:e211136. DOI PubMed PMC

23. Kim CG, Kim KH, Pyo KH, et al. Hyperprogressive disease during PD-1/PD-L1 blockade in patients with non-small-cell lung cancer. Ann Oncol 2019;30:1104-13. DOI PubMed

24. Kim SH, Choi CM, Lee DH, et al. Clinical outcomes of nivolumab in patients with advanced non-small cell lung cancer in real-world practice, with an emphasis on hyper-progressive disease. J Cancer Res Clin Oncol 2020;146:3025-36. DOI PubMed

25. Kang DH, Chung C, Sun P, et al. Circulating regulatory T cells predict efficacy and atypical responses in lung cancer patients treated with PD-1/PD-L1 inhibitors. Cancer Immunol Immunother 2021. DOI PubMed

26. Chen Y, Hu J, Bu F, Zhang H, Fei K, Zhang P. Clinical characteristics of hyperprogressive disease in NSCLC after treatment with immune checkpoint inhibitor: a systematic review and meta-analysis. BMC Cancer 2020;20:707. DOI PubMed PMC

27. Chubachi S, Yasuda H, Irie H, et al. A case of non-small cell lung cancer with possible "disease flare" on nivolumab treatment. Case Rep Oncol Med 2016;2016:1075641. DOI PubMed PMC 
28. Bernal Vaca L, Mendoza SD, Vergel JC, Rueda X, Bruges R. Hyperprogression in pediatric melanoma metastatic to the breast treated with a checkpoint inhibitor. Cureus 2019;11:e3859. DOI

29. Kanazu M, Edahiro R, Krebe H, et al. Hyperprogressive disease in patients with non-small cell lung cancer treated with nivolumab: a case series. Thorac Cancer 2018;9:1782-7. DOI PubMed PMC

30. Liu C, Piao J, Shang Z. Hyperprogressive disease after radiotherapy combined with anti-PD-1 therapy in renal cell carcinoma: a case report and review of the literature. BMC Urol 2021;21:42. DOI PubMed PMC

31. Park JH, Chun SH, Lee YG, et al. Hyperprogressive disease and its clinical impact in patients with recurrent and/or metastatic head and neck squamous cell carcinoma treated with immune-checkpoint inhibitors: Korean cancer study group HN 18-12. J Cancer Res Clin Oncol 2020;146:3359-69. DOI PubMed

32. $\mathrm{Xu} \mathrm{Z}$, Chen L, Zheng L, et al. Hyperprogressive disease in cervical small cell carcinoma treated by immune checkpoint inhibitor. Onco Targets Ther 2019;12:8873-7. DOI PubMed PMC

33. Sun D, Liu D, Liu Q, Hou H. Nivolumab induced hyperprogressive disease in advanced esophageal squamous cell carcinoma. Cancer Biol Ther 2020;21:1097-104. DOI PubMed PMC

34. Barham W, Guo R, Park SS, Herrmann J, Dong H, Yan Y. Case report: simultaneous hyperprogression and fulminant myocarditis in a patient with advanced melanoma following treatment with immune checkpoint inhibitor therapy. Front Immunol 2020;11:561083. DOI PubMed PMC

35. Yang N, Zhang PL, Liu ZJ. Iodine-125 radioactive particles antagonize hyperprogressive disease following immunotherapy: a case report. Medicine (Baltimore) 2020;99:e22933. DOI PubMed PMC

36. Peng Y, Zhang L, Zeng T, et al. Characterization of hyperprogression after immunotherapy in a lung adenocarcinoma patient with strong expression of programmed death ligand 1. J Thorac Oncol 2020;15:e4-8. DOI PubMed

37. Feng D, Guan Y, Liu M, et al. Excellent response to atezolizumab after clinically defined hyperprogression upon previous treatment with pembrolizumab in metastatic triple-negative breast cancer: a case report and review of the literature. Front Immunol 2021;12:608292. DOI PubMed PMC

38. Sama S, Hadfield MJ, Lopetegui Lia N, Vredenburgh J. Hyperprogression in PDL1 expressive, recurrent gastroesophageal-junction adenocarcinoma after pembrolizumab. Cureus 2019;11:e4862. DOI PubMed PMC

39. Iwai Y, Hamanishi J, Chamoto K, Honjo T. Cancer immunotherapies targeting the PD-1 signaling pathway. J Biomed Sci 2017;24:26. DOI PubMed PMC

40. Pardoll DM. The blockade of immune checkpoints in cancer immunotherapy. Nat Rev Cancer 2012;12:252-64. DOI PubMed PMC

41. Keir ME, Butte MJ, Freeman GJ, Sharpe AH. PD-1 and its ligands in tolerance and immunity. Anпu Rev Immunol 2008;26:677-704. DOI PubMed

42. Marcucci F, Rumio C. The tumor-promoting effects of the adaptive immune system: a cause of hyperprogressive disease in cancer? Cell Mol Life Sci 2021;78:853-65. DOI PubMed

43. Kmieciak M, Knutson KL, Dumur CI, Manjili MH. HER-2/neu antigen loss and relapse of mammary carcinoma are actively induced by T cell-mediated anti-tumor immune responses. Eur J Immunol 2007;37:675-85. DOI PubMed PMC

44. Facoetti A, Nano R, Zelini P, et al. Human leukocyte antigen and antigen processing machinery component defects in astrocytic tumors. Clin Cancer Res 2005;11:8304-11. DOI PubMed

45. Marcucci F, Rumio C, Corti A. Tumor cell-associated immune checkpoint molecules - drivers of malignancy and stemness. Biochim Biophys Acta Rev Cancer 2017;1868:571-83. DOI PubMed

46. Breunig C, Pahl J, Küblbeck M, et al. MicroRNA-519a-3p mediates apoptosis resistance in breast cancer cells and their escape from recognition by natural killer cells. Cell Death Dis 2017;8:e2973. DOI PubMed PMC

47. Noh KH, Kim SH, Kim JH, et al. API5 confers tumoral immune escape through FGF2-dependent cell survival pathway. Cancer Res 2014;74:3556-66. DOI PubMed PMC

48. Brenner E, Schörg BF, Ahmetlić F, et al. Cancer immune control needs senescence induction by interferon-dependent cell cycle regulator pathways in tumours. Nat Commun 2020;11:1335. DOI PubMed PMC

49. Romeo E, Caserta CA, Rumio C, Marcucci F. The vicious cross-talk between tumor cells with an EMT phenotype and cells of the immune system. Cells 2019;8:460. DOI PubMed PMC

50. Singavi A, Menon S, Kilari D, et al. Predictive biomarkers for hyper-progression (HP) in response to immune checkpoint inhibitors (ICI) - analysis of somatic alterations (SAs). Ann Oncol 2017;28:v405. DOI

51. Economopoulou P, Anastasiou M, Papaxoinis G, et al. Patterns of response to immune checkpoint inhibitors in association with genomic and clinical features in patients with head and neck squamous cell carcinoma (HNSCC). Cancers (Basel) 2021;13:286. DOI PubMed PMC

52. Zhao K, Yang Y, Zhang G, et al. Regulation of the Mdm2-p53 pathway by the ubiquitin E3 ligase MARCH7. EMBO Rep 2018;19:305-19. DOI PubMed PMC

53. Kato S, Ross JS, Gay L, et al. Analysis of MDM2 amplification: next-generation sequencing of patients with diverse malignancies. JCO Precis Oncol 2018:2018. DOI PubMed PMC

54. Fang DD, Tang Q, Kong Y, et al. MDM2 inhibitor APG-115 synergizes with PD-1 blockade through enhancing antitumor immunity in the tumor microenvironment. J Immunother Cancer 2019;7:327. DOI PubMed PMC

55. Sahin I, Zhang S, Navaraj A, et al. AMG-232 sensitizes high MDM2-expressing tumor cells to T-cell-mediated killing. Cell Death Discov 2020;6:57. DOI PubMed PMC

56. Montesinos P, Beckermann BM, Catalani O, et al. MIRROS: a randomized, placebo-controlled, phase III trial of cytarabine \pm idasanutlin in relapsed or refractory acute myeloid leukemia. Future Oncol 2020;16:807-15. DOI PubMed PMC 
57. Konopleva M, Martinelli G, Daver N, et al. MDM2 inhibition: an important step forward in cancer therapy. Leukemia 2020;34:285874. DOI PubMed

58. Sun L, Zhang L, Yu J, et al. Clinical efficacy and safety of anti-PD-1/PD-L1 inhibitors for the treatment of advanced or metastatic cancer: a systematic review and meta-analysis. Sci Rep 2020;10:2083. DOI PubMed PMC

59. Sugiyama E, Togashi Y, Takeuchi Y, et al. Blockade of EGFR improves responsiveness to PD-1 blockade in EGFR-mutated nonsmall cell lung cancer. Sci Immunol 2020;5:eaav3937. DOI PubMed

60. Akbay EA, Koyama S, Carretero J, et al. Activation of the PD-1 pathway contributes to immune escape in EGFR-driven lung tumors. Cancer Discov 2013;3:1355-63. DOI PubMed PMC

61. Xiong D, Wang Y, Singavi AK, Mackinnon AC, George B, You M. Immunogenomic landscape contributes to hyperprogressive disease after anti-PD-1 immunotherapy for cancer. iScience 2018;9:258-77. DOI PubMed PMC

62. Tay C, Qian Y, Sakaguchi S. Hyper-progressive disease: the potential role and consequences of T-regulatory cells foiling anti-PD-1 cancer immunotherapy. Cancers (Basel) 2020;13:48. DOI PubMed PMC

63. Gallimore A, Quezada SA, Roychoudhuri R. Regulatory T cells in cancer: where are we now? Immunology 2019;157:187-9. DOI PubMed PMC

64. Kamada T, Togashi Y, Tay C, et al. PD- $1^{+}$regulatory T cells amplified by PD-1 blockade promote hyperprogression of cancer. Proc Natl Acad Sci U S A 2019;116:9999-10008. DOI PubMed PMC

65. Shang B, Liu Y, Jiang SJ, Liu Y. Prognostic value of tumor-infiltrating FoxP3+ regulatory T cells in cancers: a systematic review and meta-analysis. Sci Rep 2015;5:15179. DOI PubMed PMC

66. Ono M, Yaguchi H, Ohkura N, et al. Foxp3 controls regulatory T-cell function by interacting with AML1/Runx1. Nature 2007;446:685-9. DOI PubMed

67. Wu Y, Borde M, Heissmeyer V, et al. FOXP3 controls regulatory T cell function through cooperation with NFAT. Cell 2006;126:375-87. DOI PubMed

68. Sawant DV, Yano H, Chikina M, et al. Adaptive plasticity of IL- $10^{+}$and IL- $35^{+} \mathrm{T}_{\text {reg }}$ cells cooperatively promotes tumor $\mathrm{T}$ cell exhaustion. Nat Immunol 2019;20:724-35. DOI PubMed PMC

69. Turnis ME, Sawant DV, Szymczak-Workman AL, et al. Interleukin-35 limits anti-tumor immunity. Immunity 2016;44:316-29. DOI PubMed PMC

70. Lin JT, Martin SL, Xia L, Gorham JD. TGF-beta 1 uses distinct mechanisms to inhibit IFN-gamma expression in CD4+ T cells at priming and at recall: differential involvement of Stat4 and T-bet. J Immunol 2005;174:5950-8. DOI PubMed

71. Ring S, Pushkarevskaya A, Schild H, et al. Regulatory T cell-derived adenosine induces dendritic cell migration through the EpacRap1 pathway. J Immunol 2015;194:3735-44. DOI PubMed

72. Onishi Y, Fehervari Z, Yamaguchi T, Sakaguchi S. Foxp3+ natural regulatory T cells preferentially form aggregates on dendritic cells in vitro and actively inhibit their maturation. Proc Natl Acad Sci U S A 2008;105:10113-8. DOI PubMed PMC

73. Qureshi OS, Zheng Y, Nakamura K, et al. Trans-endocytosis of CD80 and CD86: a molecular basis for the cell-extrinsic function of CTLA-4. Science 2011;332:600-3. DOI PubMed PMC

74. Gavin MA, Rasmussen JP, Fontenot JD, et al. Foxp3-dependent programme of regulatory T-cell differentiation. Nature 2007;445:771-5. DOI PubMed

75. Boross P, Arandhara VL, Martin-Ramirez J, et al. The inhibiting Fc receptor for IgG, Fc $\gamma R$ IIB, is a modifier of autoimmune susceptibility. J Immunol 2011;187:1304-13. DOI PubMed

76. Murakami T, Tanaka N, Takamatsu K, et al. Multiplexed single-cell pathology reveals the association of CD8 T-cell heterogeneity with prognostic outcomes in renal cell carcinoma. Cancer Immunol Immunother 2021;70:3001-13. DOI PubMed

77. Arce Vargas F, Furness AJS, Solomon I, et al; Melanoma TRACERx Consortium, Renal TRACERx Consortium, Lung TRACERx Consortium. Fc-optimized anti-CD25 depletes tumor-infiltrating regulatory T cells and synergizes with PD-1 blockade to eradicate established tumors. Immunity 2017;46:577-86. DOI PubMed PMC

78. Boisgerault N, Kottke T, Pulido J, et al. Functional cloning of recurrence-specific antigens identifies molecular targets to treat tumor relapse. Mol Ther 2013;21:1507-16. DOI PubMed PMC

79. Matsushita H, Vesely MD, Koboldt DC, et al. Cancer exome analysis reveals a T-cell-dependent mechanism of cancer immunoediting. Nature 2012;482:400-4. DOI PubMed PMC

80. Asgarova A, Asgarov K, Godet Y, et al. PD-L1 expression is regulated by both DNA methylation and NF-kB during EMT signaling in non-small cell lung carcinoma. Oncoimmunology 2018;7:e1423170. DOI PubMed PMC

81. Prestipino A, Zeiser R. Clinical implications of tumor-intrinsic mechanisms regulating PD-L1. Sci Transl Med 2019;11:eaav4810. DOI PubMed

82. Terry S, Buart S, Tan TZ, et al. Acquisition of tumor cell phenotypic diversity along the EMT spectrum under hypoxic pressure: consequences on susceptibility to cell-mediated cytotoxicity. Oncoimmunology 2017;6:e1271858. DOI PubMed PMC

83. Terry S, Savagner P, Ortiz-Cuaran S, et al. New insights into the role of EMT in tumor immune escape. Mol Oncol 2017;11:824-46. DOI PubMed PMC

84. Benci JL, Xu B, Qiu Y, et al. Tumor interferon signaling regulates a multigenic resistance program to immune checkpoint blockade. Cell 2016;167:1540-54.e12. DOI PubMed PMC

85. Minn AJ, Wherry EJ. Combination cancer therapies with immune checkpoint blockade: convergence on interferon signaling. Cell 2016;165:272-5. DOI PubMed

86. Zhang Y, Zoltan M, Riquelme E, et al. Immune cell production of interleukin 17 induces stem cell features of pancreatic intraepithelial neoplasia cells. Gastroenterology 2018;155:210-23.e3. DOI PubMed PMC 
87. Guo N, Shen G, Zhang Y, Moustafa AA, Ge D, You Z. Interleukin-17 promotes migration and invasion of human cancer cells through upregulation of MTA1 expression. Front Oncol 2019;9:546. DOI PubMed PMC

88. Kryczek I, Lin Y, Nagarsheth N, et al. IL-22(+)CD4(+) T cells promote colorectal cancer stemness via STAT3 transcription factor activation and induction of the methyltransferase DOT1L. Immunity 2014;40:772-84. DOI PubMed PMC

89. Khosravi N, Caetano MS, Cumpian AM, et al. IL22 promotes Kras-mutant lung cancer by induction of a protumor immune response and protection of stemness properties. Cancer Immunol Res 2018;6:788-97. DOI PubMed PMC

90. Landsberg J, Kohlmeyer J, Renn M, et al. Melanomas resist T-cell therapy through inflammation-induced reversible dedifferentiation. Nature 2012;490:412-6. DOI PubMed

91. Bertrand F, Montfort A, Marcheteau E, et al. TNF $\alpha$ blockade overcomes resistance to anti-PD-1 in experimental melanoma. Nat Commun 2017;8:2256. DOI PubMed PMC

92. Chen L, Heymach JV, Qin FX, Gibbons DL. The mutually regulatory loop of epithelial-mesenchymal transition and immunosuppression in cancer progression. Oncoimmunology 2015;4:e1002731. DOI PubMed PMC

93. Müller-Hermelink N, Braumüller H, Pichler B, et al. TNFR1 signaling and IFN-gamma signaling determine whether T cells induce tumor dormancy or promote multistage carcinogenesis. Cancer Cell 2008;13:507-18. DOI PubMed

94. Schürch C, Riether C, Matter MS, Tzankov A, Ochsenbein AF. CD27 signaling on chronic myelogenous leukemia stem cells activates Wnt target genes and promotes disease progression. J Clin Invest 2012;122:624-38. DOI PubMed PMC

95. Min H, Sun X, Yang X, et al. Exosomes derived from irradiated esophageal carcinoma-infiltrating T cells promote metastasis by inducing the epithelial-mesenchymal transition in esophageal cancer cells. Pathol Oncol Res 2018;24:11-8. DOI PubMed

96. Goebel L, Grage-Griebenow E, Gorys A, et al. $\mathrm{CD}^{+} \mathrm{T}$ cells potently induce epithelial-mesenchymal-transition in premalignant and malignant pancreatic ductal epithelial cells-novel implications of $\mathrm{CD}^{+} \mathrm{T}$ cells in pancreatic cancer development. Oncoimmunology 2015;4:e1000083. DOI PubMed PMC

97. Aspord C, Pedroza-Gonzalez A, Gallegos M, et al. Breast cancer instructs dendritic cells to prime interleukin 13-secreting CD4+ T cells that facilitate tumor development. $J$ Exp Med 2007;204:1037-47. DOI PubMed PMC

98. Schürch C, Riether C, Amrein MA, Ochsenbein AF. Cytotoxic T cells induce proliferation of chronic myeloid leukemia stem cells by secreting interferon- $\gamma . J$ Exp Med 2013;210:605-21. DOI PubMed PMC

99. Sanchez-Perez L, Kottke T, Diaz RM, et al. Potent selection of antigen loss variants of B16 melanoma following inflammatory killing of melanocytes in vivo. Cancer Res 2005;65:2009-17. DOI PubMed

100. Sosa MS, Bragado P, Aguirre-Ghiso JA. Mechanisms of disseminated cancer cell dormancy: an awakening field. Nat Rev Cancer 2014;14:611-22. DOI PubMed PMC

101. Ochi A, Nguyen AH, Bedrosian AS, et al. MyD88 inhibition amplifies dendritic cell capacity to promote pancreatic carcinogenesis via Th2 cells. J Exp Med 2012;209:1671-87. DOI PubMed PMC

102. McAllister F, Bailey JM, Alsina J, et al. Oncogenic Kras activates a hematopoietic-to-epithelial IL-17 signaling axis in preinvasive pancreatic neoplasia. Cancer Cell 2014;25:621-37. DOI PubMed PMC

103. Arasanz H, Zuazo M, Bocanegra A, et al. Early detection of hyperprogressive disease in non-small cell lung cancer by monitoring of systemic T cell dynamics. Cancers (Basel) 2020;12:344. DOI PubMed PMC

104. Thibult ML, Mamessier E, Gertner-Dardenne J, et al. PD-1 is a novel regulator of human B-cell activation. Int Immunol 2013;25:12937. DOI PubMed

105. Damsky W, Jilaveanu L, Turner N, et al. B cell depletion or absence does not impede anti-tumor activity of PD-1 inhibitors. $J$ Immunother Cancer 2019;7:153. DOI PubMed PMC

106. Zhao KL, Yang XJ, Jin HZ, Zhao L, Hu JL, Qin WJ. Double-edge role of B cells in tumor immunity: potential molecular mechanism. Curr Med Sci 2019;39:685-9. DOI PubMed

107. Wang $\mathrm{H}, \mathrm{Xu} \mathrm{Q}$, Zhao C, et al. An immune evasion mechanism with IgG4 playing an essential role in cancer and implication for immunotherapy. J Immunother Cancer 2020;8:e000661. DOI PubMed PMC

108. Karagiannis P, Gilbert AE, Josephs DH, et al. IgG4 subclass antibodies impair antitumor immunity in melanoma. J Clin Invest 2013;123:1457-74. DOI PubMed PMC

109. Andreu P, Johansson M, Affara NI, et al. FcRgamma activation regulates inflammation-associated squamous carcinogenesis. Cancer Cell 2010;17:121-34. DOI PubMed PMC

110. Kim SR, Chun SH, Kim JR, et al. The implications of clinical risk factors, CAR index, and compositional changes of immune cells on hyperprogressive disease in non-small cell lung cancer patients receiving immunotherapy. BMC Cancer 2021;21:19. DOI PubMed PMC

111. Lo Russo G, Moro M, Sommariva M, et al. Antibody-Fc/FcR interaction on macrophages as a mechanism for hyperprogressive disease in non-small cell lung cancer subsequent to PD-1/PD-L1 blockade. Clin Cancer Res 2019;25:989-99. DOI PubMed

112. Costantini A, Fallet V, Corny J, et al. Nivolumab-refractory patients with advanced non-small-cell lung cancer. Lung Cancer 2019;130:128-34. DOI PubMed

113. Matsuo N, Azuma K, Kojima T, et al. Comparative incidence of immune-related adverse events and hyperprogressive disease in patients with non-small cell lung cancer receiving immune checkpoint inhibitors with and without chemotherapy. Invest New Drugs 2021;39:1150-8. DOI PubMed

114. Schuiveling M, Tonk EHJ, Verheijden RJ, Suijkerbuijk KPM. Hyperprogressive disease rarely occurs during checkpoint inhibitor treatment for advanced melanoma. Cancer Immunol Immunother 2021;70:1491-6. DOI PubMed PMC

115. Hagi T, Kurokawa Y, Kawabata R, et al. Multicentre biomarker cohort study on the efficacy of nivolumab treatment for gastric cancer. Br J Cancer 2020;123:965-72. DOI PubMed PMC 
116. Kim CG, Kim C, Yoon SE, et al. Hyperprogressive disease during PD-1 blockade in patients with advanced hepatocellular carcinoma. J Hepatol 2021;74:350-9. DOI PubMed

117. Hwang I, Park I, Yoon SK, Lee JL. Hyperprogressive disease in patients with urothelial carcinoma or renal cell carcinoma treated with PD-1/PD-L1 inhibitors. Clin Genitourin Cancer 2020;18:e122-33. DOI PubMed

118. Rodriguez Freixinos V, Garcia A, Fasani R, et al. Immune profile and outcomes of patients (pts) with gynecological malignancies (GYN) enrolled in early phases immunotherapy (IO) trials. JCO 2018;36:5595. DOI

119. Chiba Y, Kawanami T, Yamasaki K, Uchimura K, Matsuyama A, Yatera K. Hyper-progressive disease after immune checkpoint inhibitor in SMARCA4-deficient small-cell lung carcinoma. Respirol Case Rep 2020;8:e00667. DOI PubMed PMC

120. Fricke J, Mambetsariev I, Pharaon R, Subbiah S, Rajurkar S, Salgia R. Hyperprogression on immunotherapy with complete response to chemotherapy in a NSCLC patient with high PD-L1 and STK11: a case report. Medicine (Baltimore) 2020;99:e22323. DOI PubMed PMC

121. Martorana F, Lanzafame K, Pavone G, et al. Early gastrointestinal progression to immunotherapy in lung cancer: a report of two cases. Case Rep Oncol Med 2021;2021:6692538. DOI PubMed PMC

122. Lin Z, Liu Q, Wei Q, Lin L, Chen X, Xue D. Hyperprogressive disease in advanced cancer patients with liver metastasis treated with PD-1 inhibitors: two case reports. Ann Transl Med 2020;8:1100. DOI PubMed PMC

123. Oguri T, Sasada S, Seki S, et al. A case of hyperprogressive disease following atezolizumab therapy for pulmonary pleomorphic carcinoma with epidermal growth factor receptor mutation. Respir Med Case Rep 2021;33:101405. DOI PubMed PMC

124. Wang W, Wu M, Liu M, et al. Hyperprogression to camrelizumab in a patient with esophageal squamous cell carcinoma harboring EGFR kinase domain duplication. J Immunother Cancer 2020;8:e00793. DOI PubMed PMC

125. Huang LT, Ma JT, Zhang SL, et al. Durable clinical response to pyrotinib after resistance to prior anti-HER2 therapy for HER2positive advanced gastric cancer: a case report. Front Oncol 2019;9:1453. DOI PubMed PMC

126. Singh B, Kaur P, Maroules M. Hyperprogression in a patient with hepatocellular cancer treated with atezolizumab and bevacizumab: a case report and review of literature. J Investig Med High Impact Case Rep 2021;9:2324709621992207. DOI PubMed PMC

127. Wong DJ, Lee J, Choo SP, Thng CH, Hennedige T. Hyperprogressive disease in hepatocellular carcinoma with immune checkpoint inhibitor use: a case series. Immunotherapy 2019;11:167-75. DOI PubMed

128. Chan KH, Lakkasani S, Ramahi A, Shaaban HS. Hyperprogressive disease in an advanced stage colon cancer patient on pembrolizumab: a case report. Cureus 2020;12:e7764. DOI PubMed PMC

129. Yilmaz M, Akovali B. Hyperprogression after nivolumab for melanoma: a case report. J Oncol Pharm Pract 2020;26:244-51. DOI PubMed

130. Forschner A, Niessner H, Möller Y, et al. Genomics of immunotherapy-associated hyperprogressors-letter. Clin Cancer Res 2017;23:6374-5. DOI PubMed

131. Koukourakis IM, Kouloulias V, Koukourakis MI. Radio-immunotherapy: a case report of 'abscopal hyper-progression'? Cureus 2020;12:e10117. DOI PubMed PMC

132. Grecea M, Marabelle A, Ammari S, Massard C, Champiat S. Managing hyperprogressive disease in the era of programmed cell death protein 1/programmed death-ligand 1 blockade: a case discussion and review of the literature. Oncologist 2020;25:369-74. DOI PubMed PMC

133. Ikushima H, Sakatani T, Ohara S, et al. Cisplatin plus pemetrexed therapy and subsequent immune checkpoint inhibitor administration for malignant peritoneal mesothelioma without pleural lesions: case report. Medicine (Baltimore) 2020;99:e19956. DOI PubMed

134. Xiang JJ, Uy NF, Minja FJ, Verter EE, Burtness BA. Hyperprogression after one dose of nivolumab in sinonasal cancer: a case report. Laryngoscope 2020;130:907-10. DOI PubMed

135. Chan AS, Ng VY, Snider J, Kallen ME, Miller KD. Hyperprogression of liver metastasis with neoadjuvant immunotherapy for soft tissue sarcoma. Cureus 2020;12:e8575. DOI PubMed PMC

136. Pandiyan P, Zheng L, Ishihara S, Reed J, Lenardo MJ. CD4+CD25+Foxp3+ regulatory T cells induce cytokine deprivation-mediated apoptosis of effector CD4+ T cells. Nat Immunol 2007;8:1353-62. DOI PubMed

137. Morris AB, Farley CR, Pinelli DF, et al. Signaling through the inhibitory Fc receptor Fc $\gamma$ RIIB induces CD $8^{+}$T cell apoptosis to limit T cell immunity. Immunity 2020;52:136-50.e6. DOI PubMed PMC 